\section{Regards sur l'économie allemande}

Bulletin économique du CIRAC

$100 \mid 2011$

Varia

\title{
Organisations patronales
}

SCHROEDER W., WEßELS B. (eds), Handbuch Arbeitgeber- und Wirtschaftsverbände in Deutschland

\section{(2) OpenEdition}

Journals

Édition électronique

URL : http://journals.openedition.org/rea/4239

DOI : $10.4000 /$ rea.4239

ISBN : 978-2-8218-0894-2

ISSN : 1965-0787

Éditeur

CIRAC

Édition imprimée

Date de publication : 17 mars 2011

ISSN : 1156-8992

Référence électronique

"Organisations patronales", Regards sur l'économie allemande [En ligne], 100 | mars 2011, mis en ligne le 19 septembre 2011, consulté le 22 septembre 2020. URL : http://journals.openedition.org/rea/4239 ; DOI : https://doi.org/10.4000/rea.4239

Ce document a été généré automatiquement le 22 septembre 2020

(c) CIRAC 


\section{Organisations patronales}

SCHROEDER W., WEßELS B. (eds), Handbuch Arbeitgeber- und Wirtschaftsverbände in Deutschland

\section{RÉFÉRENCE}

SCHROEDER W., WEßELS B. (eds), Handbuch Arbeitgeber- und Wirtschaftsverbände in Deutschland, VS Verlag für Sozialwissenschaften, Wiesbaden, 2010, 552 p.

1 Les fédérations professionnelles et patronales sont l'un des pôles de ce "parallélogramme des forces " où s'effectue la prise de décision politique et qui associe pouvoirs publics, mouvement syndical et quelques autres groupes d'intérêts constitués. Or paradoxalement, alors que les syndicats allemands sont largement connus, les organisations professionnelles et patronales - pourtant leurs partenaires institutionnels dans le 'modèle allemand' - sont amplement méconnus. Voilà, sous la direction de deux scientifiques réputés, LE manuel de référence pour comprendre la structure, l'histoire et le fonctionnement actuel de la société civile organisée en Allemagne et de ses représentations patronales. Ironie de l'histoire, l'un d'entre eux est un ancien cadre d'IG Metall et grand spécialiste du mouvement syndical. C'est dire l'ampleur des lacunes que comble cet ouvrage collectif qui révèle à quel point les mutations subies en 60 ans par le partenariat social allemand sont profondes. (ib) 